\title{
Reivindicar e resistir: conflitos coletivos de trabalho de Juiz de Fora (MG) na Justiça do Trabalho durante a ditadura brasileira (1964-1974)*
}

\author{
Claim and resist: collective labor conflicts of Juiz de Fora (MG) \\ in the Labor Justice during the Brazilian dictatorship (1964-1974)
}

\section{Paulo Henrique Silveira Damião**}

Resumo: Este artigo trata do uso da Justiça do Trabalho pelos trabalhadores da cidade de Juiz de Fora (MG) e suas representações sindicais durante a ditadura militar brasileira. Busca-se compreender o ato de reivindicar por direitos dentro dos tribunais trabalhistas como uma forma de ação e resistência da classe trabalhadora frente às políticas autoritárias da ditadura. Nesse sentido, foram utilizados como fontes documentais os processos coletivos

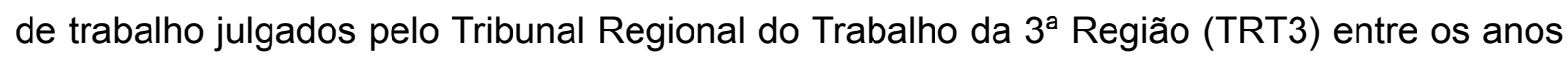
de 1964 e 1974, período em que, por muito tempo, a produção acadêmica dedicada aos mundos dos trabalhadores vinculou uma imagem de passividade e subordinação à classe trabalhadora. Dentro desse espectro, o instrumento do poder normativo torna-se fundamental para se pensar em como se deu a acolhida das demandas trabalhistas pelo TRT3.

Palavras-chave: Justiça do Trabalho; ditadura; Juiz de Fora.

Abstract: This article deals with the use of Labor Justice by the workers of the city of Juiz de Fora (MG) and their trade union representations during the brazilian military dictatorship. It seeks to understand the act of claiming for rights within the labor courts as a form of action and resistance of the working class against the authoritarian policies of the military governments.

* O presente trabalho foi realizado com apoio financeiro do CNPq, Conselho Nacional de Desenvolvimento Científico e Tecnológico - Brasil, e da CAPES, Coordenação de Aperfeiçoamento de Pessoal de Nível Superior - Brasil.

** Doutorando no Programa de Pós-Graduação em História da Universidade Estadual de Campinas (Unicamp). Bolsista do Conselho Nacional de Desenvolvimento Científico e Tecnológico (CNPq). Mestre em História pela Universidade Federal de Juiz de Fora (UFJF). E-mail: paulohenriquesd@hotmail.com. ORCID: https://orcid. org/0000-0002-1615-3429. 
In this sense, the collective labor lawsuits judged by the Tribunal Regional do Trabalho da Terceira Região (TRT3) between 1964 and 1974 were used as documentary sources, a period in which the academic production dedicated to the worlds of the workers linked an image of passivity and subordination to the working class. Within this spectrum, the instrument of normative power becomes fundamental to think about how the reception of the labor demands by the TRT3 was given.

Keywords: Labor Justice; Dictatorship; Juiz de Fora.

\section{Introdução}

A S NOÇÕES DE AGÊNCIA E RESISTÊNCIA passaram a ser, pelo menos desde a virada da década de 1970 para a de 1980, o cerne dos estudos que procuraram compreender e refletir sobre os impactos das políticas autoritárias da ditadura militar brasileira sobre os mundos dos trabalhadores, assim como para dar luz às várias formas de ações e mobilizações encontradas e desenvolvidas pelas classes trabalhadoras frente àquele Estado autoritário e repressor iniciado com o golpe de 1964 .

Do ponto de vista historiográfico, importante foi a ruptura com aquilo que se convencionou chamar de "paradigma da ausência", ocorrida em finais da década de 1970. Por muito tempo a produção acadêmica brasileira dedicada aos mundos dos trabalhadores esteve sob tal modelo analítico, de modo que nesses estudos sobressaíam percepções negativas acerca da classe trabalhadora, tal como as das chaves explicativas da passividade e subordinação. ${ }^{1}$

Influenciadas por esse modelo de análise, determinadas vertentes das ciências sociais passaram a destacar o fraco poder de organização e atuação do movimento operário e sindical durante a ditadura, reflexo da repressão e das ações de um Estado autoritário que buscava controlar, e inclusive cercear, as mobilizações dos trabalhadores. É importante ressaltar como as reflexões dos estudos identificados com o "paradigma da ausência" influenciaram a produção historiográfica que começava a se debruçar sobre questões relacionadas aos trabalhadores e ao movimento sindical durante os anos em que o Brasil esteve sob uma ditadura militar.

As teorias do populismo, a exemplo, desenvolvidas, entre os anos 1960 e 1970, por Francisco Weffort ${ }^{2}$ desempenharam forte influência sobre os estudos que buscaram

1 Acerca dos estudos que traziam uma visão subordinada da classe trabalhadora, ver mais em: RODRIGUES, Leôncio Martins. Conflito industrial e sindicalismo no Brasil. São Paulo: Difel, 1966; SIMÃO, Azis. Sindicato e Estado: suas relações na formação do proletariado de São Paulo. São Paulo: Dominus, 1966; RODRIGUES, José Albertino. Sindicato e desenvolvimento social no Brasil. São Paulo: Difel, 1968; LOPES, Juarez Brandão. Crise do Brasil arcaico. São Paulo: Difusão Europeia do Livro, 1967; LOPES, Juarez Brandão. Sociedade industrial no Brasil. São Paulo: Difusão Europeia do Livro, 1971.

2 Sobre a obra de Francisco Weffort, ver: WEFFORT, Francisco. Raízes sociais do populismo em São Paulo. Revista Civilização Brasileira, Rio de Janeiro, p. 39-60, 1965; WEFFORT, Francisco. Participação e 
compreender por que os trabalhadores não reagiram ao golpe de 1964, de modo que a primeira geração de intelectuais que tentou dar uma resposta ao questionamento acima vinculou as origens da derrota de 1964 à construção do sindicalismo varguista e ao suposto papel subalterno das esquerdas, a exemplo dos trabalhos, já citados, de José Albertino Rodrigues e Leôncio Rodrigues. ${ }^{3}$

O símbolo da mudança de percepção sobre o papel dos trabalhadores durante a ditadura militar correspondeu às greves iniciadas em 1978, no ABC paulista, e ao movimento de redemocratização do país. Nesse sentido, a produção historiográfica brasileira do pós-1978 representa uma ruptura mais precisa de paradigma, pois foi a partir dela que as diversas experiências dos trabalhadores passaram a ser resgatadas, de modo que se enfatizava, cada vez mais, o poder de organização e mobilização autônoma da classe trabalhadora. ${ }^{4}$

A partir daquele momento, os trabalhadores passaram a ser compreendidos como sujeitos sociais nas suas diversas experiências, bem como sua imagem frente à ditadura passou a ser vista sob o signo da "ação", o que levou ao desenvolvimento do "paradigma da agência". Esse movimento de renovação analítica possibilitou a publicação de inúmeras revisões historiográficas que buscaram problematizar o papel dos trabalhadores na sociedade brasileira, lançando novos olhares sobre temas já muito debatidos, como o populismo, o corporativismo ou o movimento sindical, trazendo à tona também novos problemas e enfoques, nos quais os trabalhadores apareceriam como atores e sujeitos da história. ${ }^{5}$

Este artigo busca, precisamente, contribuir com a noção de que a Justiça do Trabalho foi um importante espaço de luta e resistência para a classe trabalhadora durante a ditadura militar brasileira. Através da análise dos processos coletivos de trabalho da cidade de Juiz

conflito industrial: Contagem e Osasco, 1968. São Paulo, CEBRAP, 1972; WEFFORT, Francisco. Sindicato e política, Tese de Livre-Docência - Universidade de São Paulo, São Paulo, 1972; WEFFORT, Francisco. 0 populismo na política brasileira. $4^{\mathrm{a}}$ ed. Rio de Janeiro: Paz e Terra, 1980.

3 CORREAA, Larissa Rosa; FONTES, Paulo. As falas de Jerônimo: trabalhadores, sindicatos e a historiografia da ditadura militar brasileira. Anos 90, Porto Alegre, v. 23, n. 43, p. 129-151, jul. 2016. p. 134.

4 Ibidem, p. 137.

5 Destaca-se, entre as pesquisas que buscaram trazer novos olhares sobre a ação dos trabalhadores durante o contexto da ditadura militar brasileira, o estudo das conexões entre os locais de trabalho e as comunidades operárias, que está no cerne dos trabalhos de PESSANHA, Elina G. da Fonte. Vida operária e política. 1986. Tese (Doutorado em Ciência Social/Antropologia Social) - Universidade de São Paulo, São Paulo, 1986; RAMALHO, José Ricardo. Estado-Patrão e luta operária: o caso FMN. Rio de Janeiro: Paz e Terra, 1989; SANTANA, Marco Aurélio. Trabalho e tradição sindical no Rio de Janeiro: a trajetória dos metalúrgicos. Rio de Janeiro: DP\&A, 2001. Mais recentemente novas análises continuam surgindo, como, por exemplo, o estudo de CORRÊA, Larissa Rosa. Os "inimigos da pátria": repressão e luta dos trabalhadores do Sindicato dos Químicos de São Paulo (1964-1979). Revista Brasileira de História, São Paulo, v. 34, n. 67, p. 13-37, 2014 - a respeito das atividades de chão de fábrica, tais como panfletagem e reuniões clandestinas; ou acerca do uso da Justiça do Trabalho como uma possibilidade de se lutar por direitos, melhores salários e condições de trabalho e contra as políticas autoritárias do regime militar, a exemplo dos estudos desenvolvidos por SILVA, Claudiane Torres da. O Tribunal Regional do Trabalho na cidade do Rio de Janeiro durante a ditadura civil-militar (1964-1969). 2015. 217f. Tese (Doutorado em História, Política e Bens Culturais) - Centro de Pesquisa e Documentação de História Contemporânea do Brasil (CPDOC); SILVA, Claudiane Torres da. A Justiça do Trabalho e a ditadura civil-militar no Brasil (1964-1985): atuação e memória. 2010. 133f. Dissertação (Mestrado em História) - Universidade Federal Fluminense, Niterói, 2010; e SILVA, Fernando Teixeira da. Trabalhadores no tribunal: conflitos e Justiça do Trabalho em São Paulo no contexto do golpe de 1964. $2^{a}$ ed. São Paulo: Alameda, 2019. 
de Fora (MG), tramitados entre 1964 e 1974 no Tribunal Regional do Trabalho da $3^{\text {a }}$ Região (TRT3), ${ }^{6}$ pretende-se refletir sobre as reivindicações das classes trabalhadoras e a sua acolhida pelos juízes daquele tribunal. Procura-se, sobretudo, demonstrar que o uso do poder normativo conferido aos tribunais trabalhistas, especificamente no caso da atuação do TRT3, constituiu-se como uma possibilidade para que os trabalhadores e suas representações sindicais conquistassem direitos e aumentos salariais durante aquele contexto de autoritarismo e Estado de exceção.

\section{Movimento sindical, política econômica e repressão aos trabalhadores em Juiz de Fora}

As AÇÕES TRABALHISTAS analisadas neste artigo dizem respeito a Juiz de Fora, localizada no interior do estado de Minas Gerais, na Zona da Mata mineira, cidade que, conforme afirma Lucília Neves Delgado, foi palco de "marcantes lutas sindicais que tinham forte inspiração trabalhista". ${ }^{7}$ Por lá se destacavam um grande número de operários e, sobretudo, a indústria têxtil, que desempenhava papel importante dentro da economia mineira. Entre as décadas de 1950 e 1960, no entanto, a cidade passou por uma grande transformação, motivada pelo deslocamento do centro industrial de Minas Gerais da Zona da Mata para a capital Belo Horizonte.

Em decorrência desse movimento, a cidade perdeu sua importante posição industrial dentro da economia mineira, o que, na visão de Alessandra Silva, ocasionou uma transformação na posição de liderança da indústria local. Observa-se, a partir de então, uma diversificação do parque industrial de Juiz de Fora, com o setor têxtil assumindo diferentes contornos, identificados com a "modernização" do processo produtivo, o que representou redução de postos de trabalho e depreciação salarial. Essa transformação produziu impacto sobre os trabalhadores, que, através dos sindicatos, organizaram suas pautas reivindicatórias e estratégias de luta, sobretudo por meio da Justiça do Trabalho. ${ }^{8} \mathrm{~A}$ defesa do recurso às greves e a busca de uma organização mais autônoma dos trabalhadores, de acordo com Marcelo Badaró, caracterizava o plano sindical que, mais tarde, durante a ditadura, buscaria romper com a estrutura sindical corporativista. ${ }^{9}$

Juiz de Fora ficou marcada pelo golpe de 1964, tendo em vista que as tropas militares que depuseram João Goulart, no Rio de Janeiro, partiram da dita cidade, conforme apontam

6 As fontes utilizadas neste estudo estão sob guarda do Centro de Memória do Tribunal Regional do Trabalho

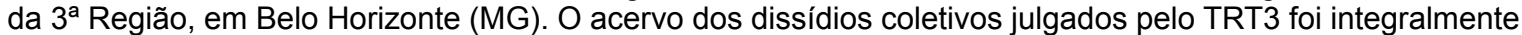
digitalizado e está disponível para consulta no site do tribunal.

7 DELGADO, Lucília de Almeida Neves. Memória, tempos vivos e história narrativa de Clodesmidt Riani. In: PAULA; CAMPOS, op. cit., p. 5.

8 SILVA, Alessandra Belo Assis. Os trabalhadores têxteis e sua luta por direitos na Justica do Trabalho (Juiz de Fora, década de 1950). 2014. 187f. Dissertação (Mestrado em História) - Universidade Federal de Juiz de Fora, Juiz de Fora. p. 170.

9 MATTOS, Marcelo Badaró. Trabalhadores e sindicatos no Brasil. São Paulo: Expressão Popular, 2009, p. 107. 
registros documentais encontrados pela Comissão Municipal da Verdade (CMV/JF). Articulada com outras cidades do país, Juiz de Fora desenvolveu uma complexa estrutura de repressão, que começou a funcionar mesmo antes da consumação do golpe. Para obter êxitos na política econômica, os governos militares criaram, por meio de legislação autoritária, "diversos mecanismos para diminuir o poder de luta dos trabalhadores, desmobilizando a ação sindical e ampliando a exploração de classe", ${ }^{10}$ de forma a facilitar o desenvolvimento de suas agendas econômicas. Intervenções sindicais, políticas que visavam restringir os aumentos salariais e repressão faziam parte do projeto autoritário da ditadura militar.

O relatório elaborado em 2014 pela Comissão Nacional da Verdade (CNV) descreve que a partir de 1964 formou-se uma aliança "empresarial-policial-militar" que buscou definir um novo regime nas fábricas. Havia, por um lado, a existência de agentes da repressão infiltrados entre os operários, que repassavam informações aos órgãos repressores. Por outro, o empresariado passou a financiar e apoiar de forma material, logística e ideológica a organização da repressão, construindo a sua face operativa e a configuração de um novo poder disciplinador, que resultou no crescimento econômico com segurança e concentração de renda. Como demonstrado pela CNV, o terror e o controle voltavam-se para a classe trabalhadora. ${ }^{11}$

A história de Juiz de Fora nos ajuda a compreender a forma como os governos militares instituíram a perseguição e a repressão aos líderes sindicais e militantes de esquerda. Os trabalhos realizados pela CMV/JF dão notícias da prisão política de sindicalistas juiz-foranos antes mesmo do fatídico 31 de março, prática que seria cada vez mais comum durante a ditadura. Foram os casos de Misael Cardoso Teixeira, diretor regional dos Correios, e José Villani Côrtes, presidente do Sindicato dos Bancários e da Cooperativa de Consumo dos Bancários, presos nas vésperas do golpe. ${ }^{12}$

A CMV/JF identificou também 151 casos de violações de direitos humanos que tiveram relação com Juiz de Fora. Dentro desse universo, estudantes, profissionais liberais (advogados, médicos, jornalistas etc.) e operários em geral chegaram a representar mais de $50 \%$ das vítimas. Entre elas encontram-se os sindicalistas José Villani e Francisco Afonso Pinheiro, mencionados anteriormente. Esses números confirmam que de fato os governos militares direcionaram suas ações aos trabalhadores e seus sindicatos, buscando conter os "avanços dos movimentos organizados de trabalhadores no campo e na cidade". ${ }^{13}$

Essa agitação militar ocorrida em Juiz de Fora dias antes da partida das tropas foi desencadeada pela articulação de duas operações orquestradas pelo general Olympio

10 MATTOS, op. cit., p. 106.

11 BRASIL. Comissão Nacional da Verdade. Relatório, v. II, textos temáticos/Comissão Nacional da Verdade. Brasília: CNV, 2014. p. 64-72.

12 JUIZ DE FORA. Memórias da repressão: relatório da Comissão Municipal da Verdade de Juiz de Fora. Juiz de Fora: MAMM, 2015. p. 46-47.

13 MATTOS, op. cit., p. 101. 
Mourão Filho, então comandante da $4^{a}$ Região Militar, sediada na cidade. A primeira, chamada Operação Silêncio, ficou responsável pela ocupação e controle das estações telefônicas, de rádio e de televisão, do Departamento dos Correios e Telégrafos e de jornais, com objetivo de facilitar as comunicações entre os militares, bem como de censurar as informações que seriam veiculadas naqueles próximos dias. Paralelamente, foi colocada em prática a Operação Gaiola, direcionada às sedes de partidos políticos e de sindicatos da cidade. As duas operações, em atividade antes mesmo do golpe de 1964, esclarecem as prisões do diretor regional dos Correios e do presidente do Sindicato dos Bancários. ${ }^{14}$

As operações destacadas acima deram subsídios para a articulação de uma terceira, que viria a retirar João Goulart da Presidência do país, a Operação Popeye, uma alusão ao cachimbo constantemente utilizado pelo general Mourão Filho. O próprio general havia relatado que, uma semana após sua posse no comando da $4^{a}$ Região Militar, em agosto de 1963, já havia iniciado, junto ao governador de Minas Gerais Magalhães Pinto e ao general Carlos Luiz Guedes, lotado na $4^{\text {a }}$ Divisão de Infantaria, em Belo Horizonte, as conspirações contra o governo Goulart. ${ }^{15}$

Com um movimento sindical atuante, a ação dos governos militares no pós-golpe para desmobilizar a organização dos trabalhadores repercutia em Juiz de Fora. Devido à crise das fábricas de tecidos e vestuário, outros setores passaram a se destacar no cenário econômico local, a exemplo dos bancos e das indústrias metalúrgicas. Nos depoimentos colhidos pela CMV/JF encontram-se relatos de pessoas que eram diretamente ligadas ao sindicalismo da cidade e que foram perseguidas pela ditadura, histórias de vida que ajudam a compreender como se articulava o sindicalismo da cidade.

Há, nesse sentido, o relato do sindicalista José Villani, que descreveu como era a atuação do Sindicato dos Bancários, do qual era presidente. Villani conta que o seu movimento "era o mais... assim, vamos dizer, corajoso, mais atrevido pra época, eu movimentava muito mais, fazia greve, fechava os bancos [...]". ${ }^{16}$ Essa mobilização sindical, sobretudo em defesa dos direitos dos trabalhadores, viria a ser reprimida pela ditadura e pela parcela conservadora da sociedade civil, que acreditava que os sindicatos eram braços do PCB e, portanto, uma grande "ameaça" à segurança nacional.

Francisco Carlos Limp Pinheiro, por sua vez, foi convidado a contar um pouco da história de seu pai, Francisco Afonso Pinheiro, funcionário da Companhia Mineira de Eletricidade, que teve forte atuação dentro do sindicato dos eletricitários. Afonso Pinheiro, outra vítima da ditadura, era filiado ao PTB e vereador de Juiz de Fora na legislatura que estava em vigor em 1964, mas, a pedido do general Mourão, foi cassado, perdendo seus direitos políticos. ${ }^{17} \mathrm{De}$ acordo com o depoimento de seu filho:

14 JUIZ DE FORA, op. cit., p. 48.

15 Ibidem, p. 48-49.

16 CÔRTES, José Villani. Depoimento dado à CMV-JF em 12 de setembro de 2014. Entrevistado por: Fernanda Sanglard e Rosali Henriques. Transcrição de: Rebeca Angel.

17 JUIZ DE FORA, op. cit., p. 69. 
[...] o movimento sindical era tanto que o PTB tinha quatro vereadores, né? [...] O partido era forte. Além de ter o Clodesmidt Riani, como deputado estadual, presidente da Central Geral dos Trabalhadores, né? Meu pai também chegou a participar da Federação dos Trabalhadores das Indústrias Urbanas do Brasil, ele foi um período. Inclusive, morou no Rio de Janeiro, né? [...] Então, ele tinha uma certa articulação nacional, também, né? O PTB aqui era muito representativo nacionalmente, tanto é... porque era liderado pelo Clodesmidt Riani, né? ${ }^{18}$

A menção a Clodesmidt Riani ${ }^{19}$ é singular, pois sua atuação como líder sindical foi, tanto local quanto nacionalmente, expressiva. Riani ingressou na luta sindical ainda nos anos 1940 e, durante sua trajetória política, participou ativamente da Comissão de Salários dos Empregados das Empresas de Carris Urbanos de Juiz de Fora, foi membro da Comissão do Salário-Mínimo do estado de Minas Gerais, nomeado, em 1954, por João Goulart, e, já na década de 1960, presidente da Confederação Nacional dos Trabalhadores nas Indústrias (CNTI), do Comando Geral dos Trabalhadores (CGT) e do Comando Estadual dos Trabalhadores do Estado de Minas Gerais (CET). Ainda em 1954 havia sido eleito deputado estadual pelo Partido Trabalhista Brasileiro (PTB), exercendo o cargo por mais de 10 anos, até que, em 1964, foi preso, torturado e teve o mandato cassado, tendo seus direitos políticos suspensos por dez anos. ${ }^{20}$

É notório que o ativismo político e sindical de Clodesmidt Riani, contado através de sua trajetória de vida, teve grande repercussão pelo país. No entanto, é preciso reconhecer que sua história está intimamente ligada à mobilização dos trabalhadores de Juiz de Fora, de modo que o sindicalismo da cidade se organizava em um plano maior, tendo em vista sua atuação em organizações sindicais estaduais e nacionais, como o CET, o CGT e a CNTI. Apesar desses indícios acerca da atuação dos sindicatos de Juiz de Fora durante a ditadura, a produção historiográfica que se debruçou sobre o contexto ditatorial da cidade, ainda muito exígua, não nos permite compreender mais a fundo o modo como o golpe militar e o autoritarismo do período impactaram os diversos sindicatos da cidade.

Como veremos a seguir, a crise econômica atravessada por Juiz de Fora seria agravada com o desenvolvimento das políticas econômico-salariais da ditadura. A inflação e a constante elevação dos preços das mercadorias de primeira necessidade contribuíam para o aprofundamento da carência dos trabalhadores e de suas famílias, fato confirmado através da anexação de relatórios do Serviço de Estatística da Previdência e Trabalho aos autos trabalhistas, por meio dos quais os trabalhadores reclamavam da perda do poder aquisitivo dos seus salários.

$\mathrm{Na}$ tentativa de conseguirem a correção salarial de acordo com os índices do custo de vida, e tendo em vista a perseguição sistemática sofrida dia a dia, os trabalhadores de

18 PINHEIRO, Francisco Carlos Limp. Depoimento dado à CMV-JF em 31 de outubro de 2014. Entrevistado por: Cristina Guerra e Rosali Henriques. Transcrição de: Marcelo Riceputi.

19 Sobre a trajetória de Clodesmidt Riani, ver: PAULA, Hilda Rezende; CAMPOS, Nilo de Araújo (org.). Clodesmidt Riani: trajetória. Juiz de Fora: Funalfa, 2005.

20 JUIZ DE FORA, op. cit., p. 162. 
Juiz de Fora e suas representações sindicais ingressavam com ações trabalhistas na Justiça do Trabalho. Naquele período de autoritarismo e repressão, no qual o movimento operário e sindical era constantemente atacado, o recurso à justiça trabalhista foi uma das poucas possibilidades encontradas para que a classe trabalhadora lutasse contra a precarização das relações de trabalho e de seus salários, uma forma de resistência à rígida política salarial praticada pelos governos da ditadura.

Nas próximas seções será feita uma breve apresentação sobre a Justiça do Trabalho, com especial atenção ao que se configura como poder normativo, destacando-se a importância desse instrumento dentro dos conflitos trabalhistas. Em seguida, serão apresentados os contornos das políticas salariais dos governos militares e suas implicações nas reivindicações dos trabalhadores, para então podermos refletir sobre os resultados dos processos analisados, buscando perceber como se deu a ação do poder normativo da Justiça do Trabalho nos julgamentos desses processos e de que modo as sentenças normativas proporcionaram algum tipo de melhoria nas relações de trabalho durante o contexto ditatorial.

\section{Conflitos trabalhistas em um Estado autoritário}

INSTITUÍDA NO BRASIL pela Constituição de 1934 e inaugurada em 1941, sob o Estado Novo (1937-1945), ${ }^{21}$ a Justiça do Trabalho surgiu com o objetivo de dirimir questões entre empregados e empregadores, visando "criar um fórum especial para que patrões e empregados resolvessem suas disputas na presença mediadora do poder público. Através de uma justiça especial, procurava-se atender aos interesses de trabalhadores e patrões de forma a evitar conflitos e greves". ${ }^{22}$

Fernando Teixeira da Silva argumenta que a Justiça do Trabalho foi criada com a "finalidade de conciliar e arbitrar os dissídios trabalhistas por meio da regulação legal de conflitos individuais e coletivos", de modo que sua constituição "integra o projeto corporativista, definido aqui como uma política estatal de representação de interesses exercida exclusivamente por grupos e associações". ${ }^{23}$ Silva lembra ainda que seu arranjo institucional é tripartite, ou seja,

21 A Justiça do Trabalho foi criada em 1934, sob o governo de Getúlio Vargas, vindo a integrar a estrutura do Ministério do Trabalho. Defensores da Justiça do Trabalho alegavam que o trabalhador brasileiro sempre foi desprotegido e que assim conseguiriam manter seus direitos. Alegavam, também, que a Justiça do Trabalho agilizaria os processos, visto que a justiça comum era muito lenta, e nesses casos precisavam de certa urgência. Assim, veicula-se a Justiça do Trabalho como um canal destinado à defesa dos direitos dos trabalhadores. Para saber mais: MOREL, Regina Lúcia; PESSANHA, Elina G. da Fonte. A Justiça do Trabalho. Tempo Social: revista de sociologia da USP, v. 19, n. 2, nov. 2007. Uma reflexão mais detida acerca do percurso da Justiça do Trabalho, inclusive desde antes de sua criação e inauguração, encontra-se em GOMES, Ângela de Castro; SILVA, Fernando Teixeira da. Os direitos sociais e humanos dos trabalhadores no Brasil: a título de apresentação. In: A Justiça do Trabalho e sua história: os direitos dos trabalhadores no Brasil. Campinas: Editora da Unicamp, 2013.

22 D'ARAUJO, Maria Celina. Estado, classe trabalhadora e políticas sociais. In: FERREIRA, Jorge; DELGADO, Lucília de Almeida (org.). O Brasil Republicano: o tempo do Nacional-Estatismo. Rio de Janeiro: Civilização Brasileira, 2003. p. 233.

23 SILVA, Trabalhadores no tribunal, op. cit., p. 48. 
expressa uma relação entre capital, trabalho e Estado, e hierárquico, objetivando alcançar a "paz social" e atender ao interesse público. ${ }^{24}$

Com a Constituição de 1946, a Justiça do Trabalho sofreu algumas alterações importantes em sua estrutura, das quais duas foram determinantes para uma nova configuração: sua passagem para o Poder Judiciário, visto que até então estava atrelada ao Ministério do Trabalho, portanto ao Poder Executivo, e a instituição do seu poder normativo, que, de acordo com Claudiane Silva, seria "a competência constitucional dos tribunais do trabalho para proferir decisões nos processos de dissídios criando condições de trabalho com força obrigatória". ${ }^{25}$ Portanto, a competência normativa conferida à Justiça do Trabalho constitui, na visão de Fernando Teixeira da Silva, "o instrumento de que se vale o Estado para intervir no conflito capital versus trabalho no plano coletivo", ${ }^{26}$ estabelecendo novas e mais benéficas condições de trabalho.

Alisson Droppa nos lembra de que a polêmica em torno da possibilidade da Justiça do Trabalho intervir no conflito coletivo de trabalho, uma vez que "é no âmbito do processo coletivo que o Poder Judiciário utiliza o poder normativo para estabelecer normas", ${ }^{27}$ já estava posta nos anos 1930, quando das discussões em torno da instituição daquela justiça, tendo Waldemar Ferreira e Oliveira Vianna como principais interlocutores. ${ }^{28}$

A Justiça do Trabalho, em conjunto com as ações dos trabalhadores e dos sindicatos, apresentava-se como um grande empecilho para a reforma de Estado, sobretudo no plano econômico-salarial que os militares pretendiam realizar. Droppa afirma que os aumentos salariais concedidos pela Justiça do Trabalho afetavam diretamente suas políticas anti-inflacionárias. ${ }^{29}$ Diante da crise econômica que se alastrava, da qual a ditadura se impunha como solução, o presidente Castelo Branco nomeou Octávio Gouvêa de Bulhões para o Ministério da Fazenda e Roberto Campos para o Ministério do Planejamento. Ambos seriam responsáveis pelo desenvolvimento do plano econômico de governo, lançado oficialmente em novembro de 1964. Denominado Programa de Ação Econômica do Governo (PAEG), o plano continha as principais políticas e reformas pretendidas pela equipe econômica.

O prenúncio de que uma nova política salarial seria colocada em prática foi dado no momento da assinatura da Lei $n^{\circ} 4.330$, de 1 de junho de 1964, que, por burocratizar os procedimentos e prazos relacionados à deflagração de greves, praticamente inviabilizando-as, ficou conhecida como "lei antigreve". ${ }^{30}$ Naquele momento, Castelo Branco anunciou que caberia ao Poder Executivo ditar as regras de reajuste salarial. Por consequência, a Justiça

24 Ibidem.

25 SILVA, Claudiane Torres da. A Justiça do Trabalho e a ditadura civil-militar no Brasil (1964-1985): atuação e memória. 2010. 133f. Dissertação (Mestrado em História) - Universidade Federal Fluminense, Niterói. p. 43.

26 SILVA, Trabalhadores no tribunal, op. cit., p. 48.

27 DROPPA, Alisson. O poder normativo e a consolidação da Justiça do Trabalho brasileira: a história da jurisprudência sobre o direito coletivo de trabalho. Tempo (Niterói, online), v. 22, n. 40, p. 231, maio-ago. 2016.

28 Ibidem, p. 227.

29 DROPPA, op. cit., p. 234.

30 BRASIL. Lei $n^{\circ} \mathbf{4 . 3 3 0}$, de 1 de junho de 1964. Regula o direito de greve na forma do art. 158 da Constituição Federal. Brasília: Diário Oficial da União, seção 1, 3 jun. 1964. p. 4713. 
do Trabalho, que exercia a função de determinar os aumentos salariais, ficaria subordinada aos atos do Poder Executivo, o que minava, em parte, o instrumento normativo. ${ }^{31}$

Em 19 de junho de 1964, ou seja, 19 dias após a publicação da lei "antigreve", foi publicado o primeiro documento que estabeleceu critérios específicos para a nova política salarial. A Circular $n^{\circ} 10$, caracterizada "como uma espécie de 'código genético' da política salarial do governo militar [...], serviu de orientação para o conjunto de normas e decretos editados posteriormente". ${ }^{32}$ Esse documento estabelecia a necessidade de reorganização do Conselho Nacional de Política Salarial (CNPS), definindo que nenhum reajustamento, revisão ou acordo salarial de caráter coletivo, na área de serviço público federal ou de empresas privadas que prestassem serviços públicos à União, poderia ser realizado sem a prévia consulta ao CNPS. ${ }^{33}$

Em 14 de julho de 1964, o governo publicou o Decreto $n^{\circ} 54.018$, consolidando o texto da Circular $n^{\circ} 10$, de modo que o CNPS passou a ser o órgão definidor da política salarial do funcionalismo público do país. O governo foi mais além, com aquele decreto colocava-se o método de reajustamento como diretriz da política salarial do governo federal, de modo que o Ministério Público do Trabalho (MPT) deveria sustentar tal orientação nos casos de dissídio coletivo, ou seja, perante os tribunais do trabalho. O MPT passaria, a partir de então, a ter uma atuação que buscaria fazer com que a Justiça do Trabalho adotasse e seguisse as normas contidas no referido decreto. ${ }^{34}$

Por meio das ações coletivas de Juiz de Fora tramitadas no Tribunal Regional do Trabalho da $3^{a}$ Região (TRT3) entre julho e dezembro de 1964, foi possível perceber que os procuradores regionais do trabalho passaram, desde então, a orientar os juízes do TRT3 a exigirem a prévia consulta do CNPS antes de proferirem qualquer decisão nos dissídios. ${ }^{35} \mathrm{Em}$ contrapartidas, alguns juízes denunciavam durante os julgamentos as investidas do Executivo em buscar formas de cercear a atuação da Justiça do Trabalho, ou seja, de restringir a ação do poder normativo, a exemplo de Cândido Gomes de Freitas. ${ }^{36}$ No ano seguinte, a Procuradoria Geral do Trabalho (PGT), em parecer da lavra do procurador José Paulo Vieira, reconheceu que estava havendo "evidente conflito entre os poderes normativos conferidos nos artigos 123 da CF e 678 da CLT, e o que institui o Decreto n 54.018/64". ${ }^{37}$

Diferentemente do setor público, no qual os salários estavam sendo regulados pelo Decreto $n^{\circ} 54.018$, os reajustes salariais do setor privado eram, até então, calculados apenas

31 NAGASAVA, Heliene. O sindicato que a ditadura queria: o Ministério do Trabalho no governo Castelo Branco (1964-1967). Jundiaí: Paco Editorial, 2018. p. 52-66.

32 COSTA, Edmilson. A política salarial no Brasil (1964-1985): 21 anos de arrocho salarial e acumulação predatória. São Paulo: Boitempo Editorial, 1997. p. 123.

33 Ibidem, p. 123-124.

34 BRASIL. Decreto $n^{\circ}$ 54.018, de 14 de julho de 1964. Reorganiza o Conselho Nacional de Política Salarial, estabelece normas sobre a política salarial do governo e dá outras providências. Brasília: Diário Oficial da União, seção 1, 15 jul. 1964, p. 6273.

35 TRT3, Processos n 3.857 e 4.627, 1964.

36 TRT3, Processo $n^{\circ} 4.627,1964$.

37 Ibidem. 
pela aplicação dos índices do custo de vida aos salários percebidos pelos trabalhadores, uma fórmula que para o governo era incompatível com o combate à inflação. ${ }^{38} \mathrm{Em} 1965$, a partir do envio do Projeto $n^{\circ} 7 / 65$ ao Congresso, o governo resolveu, então, estender a política salarial adotada no âmbito do funcionalismo público às empresas privadas, a fim de se conseguir melhores êxitos na área econômica. Edmilson Costa destaca que:

Apesar do tratamento rígido dispensado aos salários dos empregados na estrutura funcional do governo e nas empresas de alguma forma ligadas ao Estado, os resultados obtidos até então pelo programa de estabilização eram bastante precários pelo fato de que a política salarial não atingia o conjunto dos trabalhadores [...]. Assim, o governo resolveu endurecer ainda mais a política salarial, estendendo também para as empresas privadas [...] os mesmos mecanismos já implementados na área pública [...]. ${ }^{39}$

No Congresso, o Projeto $n^{\circ} 7 / 65$ foi transformado na Lei $n^{\circ} 4.725$, sancionada em 13 de julho de 1965, que estabeleceu novas regras para os dissídios coletivos. Além de estender a rígida política salarial do governo aos trabalhadores do setor privado, ela simplificava a fórmula do reajuste, ao definir, em seu artigo $2^{\circ}$, que a sentença dos tribunais tomaria como base o índice resultante da reconstituição do salário real médio dos últimos 24 meses anteriores ao término da vigência do último acordo ou sentença normativa. ${ }^{40}$ Desprezava-se, portanto, a inflação, o que poderia congelar os salários ou ocasionar reajustes inferiores ao INPC, que não recomporiam o poder aquisitivo dos assalariados.

Desde o primeiro artigo daquela que ficou conhecida como "lei do arrocho salarial", o governo visava submeter a Justiça do Trabalho aos projetos do Poder Executivo, que eram enviados ao Congresso para que fossem transformados em leis. Conforme exposto por Edmilson Costa, no artigo 12 "o governo completava o círculo de ferro sobre os trabalhadores", 41 pois proibia que a Justiça do Trabalho homologasse ou determinasse reajustes salariais antes de decorrido um ano do último acordo ou dissídio coletivo. ${ }^{42}$

A lei do arrocho salarial pode ser considerada, pelo menos até 1974, como a base das políticas salarias desenvolvidas pelos governos militares. Leis e decretos publicados depois de julho de 1965 serviriam apenas para aperfeiçoar a rígida e autoritária política de contenção de salários. É o caso da Lei $n^{\circ} 4.903$, de dezembro de 1965, que estabeleceu novos critérios para realização dos cálculos de reajuste salarial, e dos decretos n 57.627, 15 e 17, todos de $1966 .{ }^{43} \mathrm{O}$ primeiro reestabeleceu o resíduo inflacionário nos cálculos salariais, já os dois

38 COSTA, op. cit., p. 126

39 Ibidem, p. 123.

40 BRASIL. Lei $\mathbf{n}^{\circ} \mathbf{4 . 7 2 5}$, de 13 de julho de 1965 . Estabelece normas para o processo dos dissídios coletivos, e dá outras providências. Brasília: Diário Oficial da União, seção 1, 14 jul. 1965, p. 6609.

41 COSTA, op. cit., p. 127

42 BRASIL. Lei $\mathbf{n}^{\circ} \mathbf{4 . 7 2 5}$, op. cit., p. 6.609.

43 BRASIL. Lei $n^{\circ} 4.903$, de 16 de dezembro de 1965. Dá nova redação ao art. $2^{\circ}$ e ao $\S 1^{\circ}$ do art. $6^{\circ}$ da Lei $n^{\circ}$ 4.725, de 13 de julho de 1965, que estabelece normas para o processo dos dissídios coletivos, e dá outras providências. Brasília: Diário Oficial da União, seção 1, 20 dez. 1965, p. 13076; BRASIL. Decreto n 57.627, de 13 de janeiro de 1966. Regulamenta o artigo $2^{\circ}$ da Lei $n^{\circ} 4.725$, de 13 de julho de 1965 , com a redação dada pela Lei $n^{\circ} 4.903$, de 16 de dezembro de 1965. Brasília: Diário Oficial da União, seção 1, 17 jan. 1966, p. 540; BRASIL. Decreto-Lei $n^{\circ} 15$, de 29 de julho de 1966. Estabelece normas e critérios para uniformização dos reajustes salariais e dá outras providências. Brasília: Diário Oficial da União, seção 1, 1 ago. 1966, p. 8667; 
últimos procuraram, em suma, centralizar a fórmula de reajustamento salarial a ser adotada pela Justiça do Trabalho em atos do Poder Executivo.

$\mathrm{Na}$ verdade, com o Decreto $\mathrm{n}^{\circ} 17$ o governo parecia, segundo Edmilson Costa, ter percebido o "torniquete salarial implementado". ${ }^{44}$ Assim, Castelo Branco buscou atenuar "algumas características mais draconianas do decreto anterior". ${ }^{45}$ Incluiu-se, no artigo $1^{\circ}$, a possibilidade de os tribunais trabalhistas corrigirem distorções salariais a partir da consideração de alguns fatores, como o resíduo inflacionário, a produtividade e a perda de poder aquisitivo, fatores semelhantes aos contidos anteriormente na Lei $n^{\circ} 4.725$.

Em direção oposta à do governo, o Tribunal Regional do Trabalho da $3^{a}$ Região vinha, paulatinamente, reafirmando que só a Justiça do Trabalho estaria mais bem capacitada para aferir as repercussões dos ajustes salariais na comunidade e na economia, bem como a adequação do reajuste do salário às necessidades do trabalhador, ajustando, assim, "o aumento às verdadeiras necessidades dos empregados [...] em consonância também com os diplomas legais disciplinadores dos dissídios coletivos (leis 4.725 e 4.903 ) [...]". ${ }^{46}$

No julgamento de uma ação movida pelo sindicato dos tecelões de Juiz de Fora, ocorrido em 8 de junho de 1966, o TRT3, através do voto do relator da ação, juiz José Carlos Guimarães, entendeu que não era obrigado a seguir os índices fornecidos pelo Conselho Nacional de Economia ou por qualquer outro órgão ligado ao Executivo, acusando o Conselho de "omitir-se na apreciação desses mesmos três fatores, dado seu conteúdo jurídico e não de mensuração econômica como ocorre quando se trata de perda de poder aquisitivo médio real do salário ocorrida entre a data da entrada da representação e a da sentença coletiva". ${ }^{47}$

Buscando corrigir os efeitos negativos dessa subestimação, o sucessor de Castelo Branco, marechal Costa e Silva, publicou, em junho de 1968, a Lei $n^{\circ} 5.451$, reordenando, mais uma vez, a política salarial. De acordo com seu texto, a partir daquele ano, nos cálculos realizados pelo CNPS, pelo Departamento Nacional do Salário (DNS) e nos processos de dissídio coletivo perante a Justiça do Trabalho, o salário reajustado seria determinado de modo a equivaler ao salário real médio dos últimos 24 meses, com acréscimo de previsão para compensação da metade do resíduo inflacionário, que traduzisse o aumento de produtividade do ano anterior. 48

Já em 1971, o Tribunal Superior do Trabalho (TST) resolveu, a fim de firmar um entendimento único a respeito dos reajustes salariais dentro das instâncias da Justiça do Trabalho, expedir o Prejulgado $n^{\circ}$ 38, de 20 de agosto de 1971, que unificava as orientações para o restante dos tribunais. Costa aponta que com o prejulgado o TST apresentava "normas

BRASIL. Decreto-Lei $n^{\circ}$ 17, de 22 de agosto de 1966. Introduz alterações em dispositivos, que menciona o Decreto-lei n 15, de 29 de julho de 1966. Brasília: Diário Oficial da União, seção 1, 23 ago. 1966, p. 9660.

44 COSTA, op. cit., p. 129.

45 Ibidem, p. 129.

46 TRT3, Processo $n^{\circ} 5.433,1965$

47 Ibidem.

48 BRASIL. Lei $n^{\circ} \mathbf{5 . 4 5 1}$, de 12 de junho de 1968. Dispõe sobre reajustamento salarial. Brasília: Diário Oficial da União, seção 1, 14 jun. 1968, p. 4857. 
tão específicas, que incluíam um conjunto de quatro tabelas com detalhes sobre a fórmula do reajuste salarial, chegando mesmo a um nível de pormenorização tal que definia até o arredondamento dos cálculos em frações decimais". ${ }^{49}$

Como veremos a seguir, as alterações na legislação trabalhista e o desenvolvimento da política salarial rígida e autoritária estiveram presentes nos conflitos trabalhistas iniciados em Juiz de Fora e levados para a arena da Justiça do Trabalho. Os trabalhadores e suas representações sindicais pautavam suas reivindicações sob os argumentos de que os salários percebidos eram incompatíveis com o custo de vida. A Justiça do Trabalho, por sua vez, como já destacado, vinha defendendo seu poder normativo, reafirmando-se como independente do Poder Executivo e como a instituição que estava melhor qualificada para arbitrar os aumentos salariais.

\section{As reivindicações trabalhistas}

AMUDANÇA DE CONJUNTURA marcada pelo golpe de 1964 pode ser percebida através dos processos da Justiça do Trabalho. A experiência democrática vivida anteriormente, na qual trabalhadores e sindicatos tiveram grande expressão política, foi, de fato, rompida. Com a ditadura militar, trabalhadores e sindicatos perderam espaços importantes para a defesa de seus direitos, senão todos, com exceção da Justiça do Trabalho. A importância desempenhada por tal instituição durante o regime autoritário pode ser atestada através do crescimento da procura dos trabalhadores ao judiciário trabalhista, o que confirma que eles estiveram buscando, via Justiça do Trabalho, a preservação, e até mesmo a expansão, de seus direitos.

De acordo com dados disponíveis no site do Tribunal Superior do Trabalho, no intervalo entre 1964 e 1974 o número de ações iniciadas na $3^{\text {a }}$ Região da Justiça do Trabalho, a qual a cidade Juiz de Fora pertence, mais que triplicou em relação ao mesmo intervalo temporal da década anterior. Apenas entre 1966 e 1970, o número de processos na Justiça do Trabalho brasileira quase dobrou, se comparado ao número de ações movidas entre 1961 e $1965 .{ }^{50}$ Nesse sentido, Larissa Corrêa argumenta que:

A alta procura dos trabalhadores ao judiciário trabalhista pode ser explicada, em parte, pelo fato de que os tribunais representaram, principalmente no período de autoritarismo do regime militar, um dos poucos canais - senão o único - de recurso dos trabalhadores para buscar reparações em relação aos direitos sistematicamente sonegados pelos patrões. ${ }^{51}$

A repressão direcionada aos trabalhadores, a criminalização das greves, as intervenções dentro dos sindicatos e as políticas econômicas autoritárias formaram, assim, um cenário no

49 COSTA, op. cit., p. 140.

50 Dados disponíveis no site do Tribunal Superior do Trabalho (Séries históricas). Disponível em: http://www.tst. jus.br/web/estatistica/jt/recebidos-e-julgados. Acesso em: 26 nov. 2018.

51 CORREA, Larissa Rosa. O corporativismo dos trabalhadores: leis e direitos na Justiça do Trabalho entre os regimes democráticos e ditatorial-militar no Brasil (1953-1978). Estudos Ibero-Americanos, Porto Alegre, v. 42, n. 2, p. 500-526, maio-ago. 2016. p. 506. 
qual o recurso ao judiciário trabalhista por meio de uma ação talvez tenha se constituído, como colocado por Corrêa, na única forma de luta, de mobilização possível para os trabalhadores naquele contexto. Através da Justiça do Trabalho buscavam assegurar seus direitos e reivindicar aumentos salariais que proporcionassem a recomposição do poder de compra dos assalariados.

Ao todo, 25 ações coletivas de trabalho envolvendo representações dos trabalhadores de Juiz de Fora foram iniciadas na Justiça do Trabalho durante os dez primeiros anos da ditadura militar. As reivindicações variavam, mas elas guardam em comum os pedidos por aumento salarial, característica natural dos dissídios coletivos, que esteve presente em 24 das 25 ações analisadas. No entanto, além da reclamação salarial, havia outras demandas bastante significativas para a classe trabalhadora, inclusive no que se refere ao tema da legislação trabalhista, visto que os sindicatos podiam, em uma mesma ação, pleitear inúmeras coisas.

Foram localizadas 75 demandas nesses processos, distribuídas entre reivindicações por aumento salarial, benefícios, carreira e vínculo profissional, condições de trabalho, remuneração e representação coletiva, tal como fez Fernando Teixeira da Silva em seu livro Trabalhadores no tribunal, onde o autor analisou os conflitos trabalhistas de São Paulo no contexto do golpe de $1964 .^{52}$

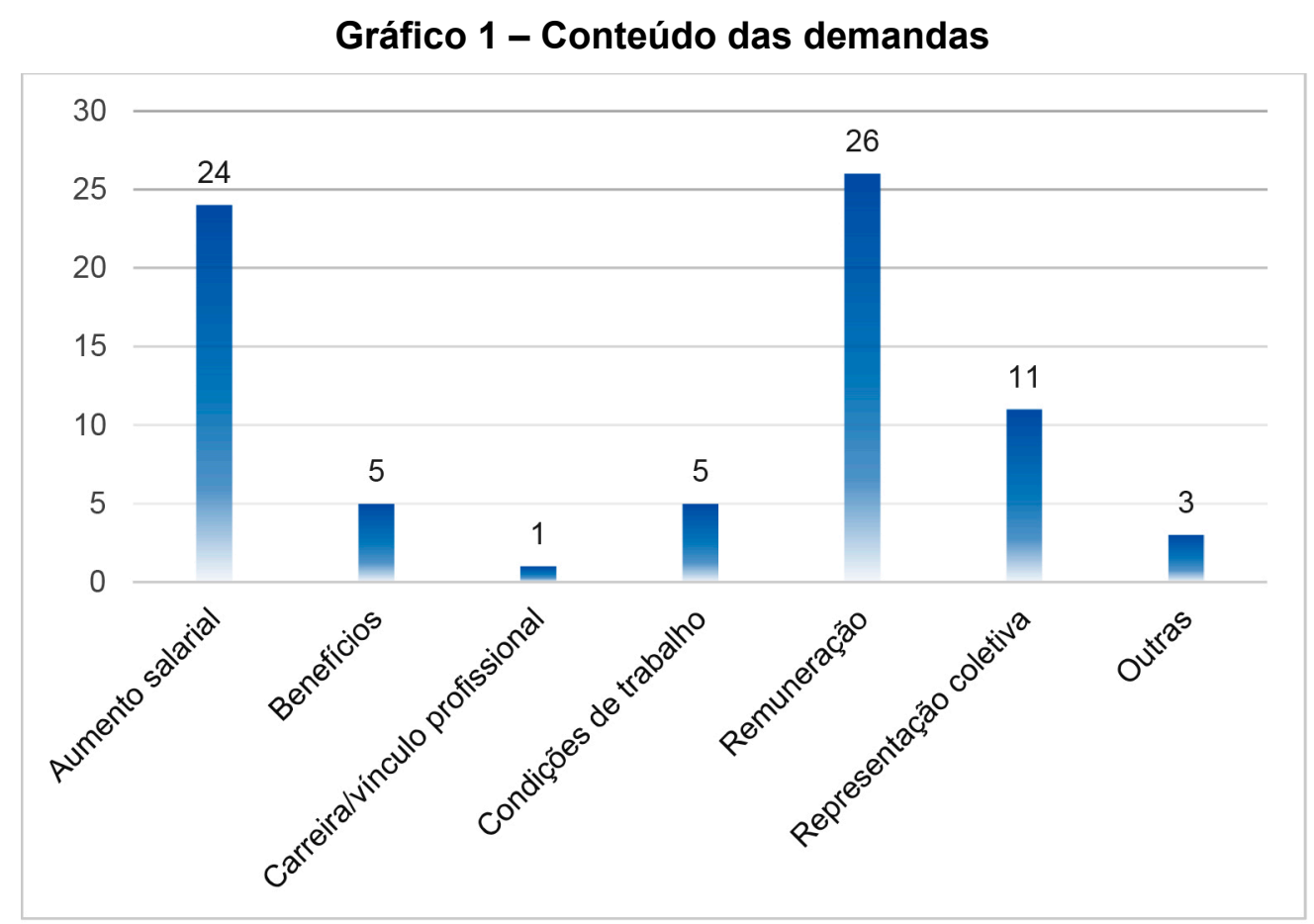

Fonte: Tribunal Regional do Trabalho da $3^{\text {a }}$ Região.

52 SILVA, Trabalhadores no tribunal, op. cit. 
O aumento salarial, principal objeto dos processos coletivos de trabalho, era reclamado pelas classes trabalhadoras devido, principalmente, à perda do poder aquisitivo dos assalariados, que, geralmente, era decorrente da alta inflacionária, da elevação dos preços das utilidades e da política de arrocho salarial desenvolvida pelos governos militares.

Em setembro de 1964, portanto alguns meses após o golpe, o presidente do Sindicato dos Trabalhadores na Indústria de Calçados de Juiz de Fora, Agostinho Circunsisão, relatou, na petição inicial da ação que movia contra o sindicato patronal da categoria, que o país estava sendo "acometido de uma alta vertiginosa, provocando a inflação um descontrole nos preços dos gêneros de primeira necessidade jamais vista, o que reflete, diretamente, sobre os componentes da categoria profissional" ${ }^{53}$ Devido à impossibilidade de a categoria profissional enfrentar o alto índice do custo de vida com o pequeno salário que percebiam, os sapateiros de Juiz de Fora se viram na necessidade de estudar com os empregadores um reajustamento salarial, que acabou por motivar a abertura da ação. ${ }^{54}$

Do mesmo modo, em fevereiro de 1965, o presidente do Sindicato dos Empregados no Comércio de Juiz de Fora Peri Rodrigues expôs que os trabalhadores do comércio não estavam em condições de suportar o elevado índice do custo de vida, sobretudo se levado em consideração o desvalorizado salário que era percebido pelos trabalhadores daquele ramo. ${ }^{55}$ Peri Rodrigues destacou, ainda, que era "público e notório que o custo de vida entrou numa espiral inflacionária, subindo dia a dia, de forma astronômica, após a vigência do último salário mínimo [decretado no início do ano anterior]. E de abril pra cá, então, a elevação é tão violenta que escapa ao controle dos próprios órgãos oficiais". ${ }^{56} \mathrm{Em}$ grande medida, os argumentos levados pelos sindicatos ao tribunal demonstram como a alta do custo de vida naqueles anos da ditadura, motivada pela inflação descontrolada, era incompatível com os salários recebidos pelos trabalhadores, conforme evidenciam os dois relatos trazidos acima.

Com relação aos benefícios, reclamava-se pela fixação de taxas, gratificações e adicionais aos salários. O Sindicato dos Condutores de Veículos Rodoviários de Juiz de Fora, por exemplo, reivindicou a fixação de uma taxa, que seria paga aos trabalhadores da categoria por dia trabalhado fora da sede. ${ }^{57}$ Já o Sindicato dos Trabalhadores na Indústria da Construção Civil de Juiz de Fora pleiteava um adicional de 10\% sobre o salário individual dos trabalhadores da categoria por execução de trabalhos com ferramentas próprias. ${ }^{58}$

No grupo das remunerações, sobressaem os pedidos para fixação de piso ou teto salarial, objeto de reclamação de variadas categorias profissionais. Foram identificadas, também, reivindicações de aumentos aos jovens aprendizes, de aumentos proporcionais aos trabalhadores que percebiam salários à base de linhas, tarefas ou comissões, e de majoração

53 TRT3, Processo $n^{\circ} 4.627,1964$.

54 Ibidem.

55 TRT3, Processo n 743, 1965.

56 Ibidem.

57 TRT3, Processo $n^{\circ} 3.857,1964$.

58 TRT3, Processo n 1.912, 1973. 
proporcional ao tempo de contratação. Ou seja, além de aumentos salariais, buscava-se melhorias nas remunerações dos trabalhadores como um todo.

No que diz respeito às condições de trabalho, encontram-se reivindicações relacionadas à jornada de trabalho. Em dois processos envolvendo a federação e os sindicatos dos bancários de Belo Horizonte, Juiz de Fora e Uberlândia, por exemplo, pedia-se a redução da jornada de trabalho para seis horas. Outra demanda encontrada no grupo das condições de trabalho foi a fixação de férias por 30 dias corridos, objeto de reclamação presente em três processos. ${ }^{59}$

Por fim, entre as demandas relacionadas à representação coletiva, a maior parte estava relacionada ao estabelecimento de um desconto de determinado valor dos salários dos trabalhadores associados às representações profissionais em prol do serviço de assistência jurídica ou de outros serviços desenvolvidos pelos seus respectivos sindicatos. Ressalta-se, porém, outra singular reclamação relacionada ao tema da representação coletiva: a liberação de dirigente sindical de suas atividades laborais. Essa reclamação esteve presente nos processos movidos pelos bancários, que pediam a respectiva liberação sem que o trabalhador perdesse sua remuneração. Os sindicatos argumentavam que o tribunal deveria conceder a liberação de um funcionário eleito para cargo de direção ou representação sindical, com direito a todas as vantagens ou melhorias, como se em serviço estivesse. ${ }^{60}$

Em vista dos objetos reclamados, entende-se o ato dos trabalhadores de reclamar por direitos trabalhistas e aumentos salariais na Justiça do Trabalho como uma forma de ação (dentre várias possíveis), ou seja, de agência dos trabalhadores durante o regime ditatorial. Ainda que os casos trazidos neste artigo se constituam como demandas coletivas, ações iniciadas pelos sindicatos que visavam beneficiar toda a categoria profissional, a abertura dos processos necessitava da aprovação individual de cada trabalhador filiado ao seu respectivo sindicato, conforme ordenamento da Consolidação das Leis do Trabalho (CLT), ${ }^{61}$ o que evidencia o apoio, mobilização e até mesmo o interesse dos trabalhadores de Juiz de Fora nas ações instauradas.

\section{A ação do poder normativo}

VIMOS ATÉ AQUI como os governos militares elaboraram e colocaram em prática uma nova agenda salarial, responsável por gerar uma significativa desvalorização da força de trabalho. O arrocho salarial que se viveu a partir de 1964 desencadeou, por sua vez, o aumento da concentração de renda e, consequentemente, das desigualdades sociais. Ao mesmo tempo em que buscava estabelecer limites aos aumentos salariais, o Poder Executivo almejava uma

59 TRT3, Processos n².380, 1970; 106, de 1972; 1.001, 1973.

60 TRT3, Processos n² 2.380, 1970; 3.135, 1972.

61 BRASIL. Decreto-Lei $n^{\circ}$ 5.452, de 1 de maio de 1943. Aprova a Consolidação das Leis do Trabalho. Brasília, Diário Oficial da União, seção 1, 9 ago. 1943, p. 11937. 
Justiça do Trabalho subordinada a seus atos, leis e decretos, ampliando o espaço de ação da política salarial, com o argumento de que assim conseguiria conter a inflação e melhorar os números econômicos.

Contra a precarização do trabalho, trabalhadores e sindicatos ingressaram com ações trabalhistas na Justiça do Trabalho, como forma de se conseguir melhores salários, remunerações e condições de trabalho, ações que tramitaram entre 1964 e 1974, naquele contexto em que apagamento e silenciamento da classe trabalhadora sobressaíam na produção acadêmica identificada com o "paradigma da ausência". Nesse sentido, busca-se dar luz à agência dos trabalhadores dentro das instâncias da Justiça do Trabalho, com o intuito de apresentar um contraponto a essa noção de ausência. Por outro lado, procura-se compreender o uso do judiciário trabalhista como uma forma de resistência ao regime autoritário.

Os processos em questão foram a julgamento no TRT3 de duas maneiras: como homologação de acordo celebrado entre as partes durante a tramitação das ações na esfera administrativa, geralmente na Delegacia Regional do Trabalho (DRT), ou durante audiência de conciliação nas Juntas de Conciliação e Julgamento ( $1^{\mathrm{a}}$ instância do judiciário trabalhista); ou como dissídio coletivo, situação em que, não havendo acordo entre as partes, os próprios juízes do tribunal definiriam se as reivindicações dos trabalhadores seriam acolhidas na sua integralidade, parcialmente, ou se seriam indeferidas.

Para uma melhor conceituação, entende-se por dissídio coletivo aqueles processos em que não há acordo prévio entre as partes litigantes nem na DRT nem nas JCJ. Nesses casos, "os juízes interferem diretamente no conflito, fixando em sentenças normativas (acórdãos) aumentos de salários e/ou modificação nas condições de trabalho". ${ }^{62}$ As homologações, por sua vez, são, de acordo com Fernando Teixeira da Silva, "processos em que as partes - sindicatos de trabalhadores, de um lado, e sindicatos patronais ou empresa(s)/empregador(es), de outro - entram livremente em acordo". ${ }^{63}$

Resguardado pelo poder normativo, que, segundo Droppa, permitiu que os juízes do trabalho exercessem a função de equilibrar as tensões sociais entre os trabalhadores e os patrões, ${ }^{64}$ o Tribunal Regional do Trabalho da $3^{\text {a }}$ Região, como veremos adiante, procurou não só recompor o poder aquisitivo dos assalariados, como também instituir alguns direitos que visavam melhorar as condições de trabalho de algumas categorias profissionais de Juiz de Fora. As sentenças normativas proferidas por um tribunal trabalhista, como bem lembrou, em uma sessão de julgamento do TRT3, o juiz Paulo Emílio Ribeiro de Vilhena, ${ }^{65}$ tinham a finalidade de uniformizar as condições de trabalho, no sentido de que "as disparidades, a

62 SILVA, Trabalhadores no tribunal, op. cit., p. 131.

63 Ibidem, p. 130.

64 DROPPA, op. cit., p. 230.

65 O juiz Ribeiro de Vilhena escreveu sobre diversos temas do Direito do Trabalho, entre eles, o poder normativo, objeto de sua tese de doutorado, transformada no livro da sentença normativa à luz da Emenda Constitucional 45/04 (São Paulo: LTr, 2006). 
desigualdade de tratamento são distorções que não coadunam com a natureza do instituto normativo, da sentença ou da convenção". 66

Ao quantificar os resultados dos dissídios, foi apurado que nenhuma ação coletiva analisada teve provimento integral e que apenas uma foi indeferida. Ou seja, a predominância esteve nas procedências parciais, que correspondem a 16 dissídios. Esses dados demonstram que em nenhum dos dissídios coletivos os trabalhadores obtiveram a integralidade das demandas reivindicadas por eles. Já em relação às homologações, em cinco delas o tribunal homologou todas as cláusulas dos acordos que foram livremente pactuados entre as partes. Já em outras três, o TRT3 excluiu alguma cláusula dos acordos, de modo que foram parcialmente homologados. Os dados informados neste parágrafo foram compilados no gráfico abaixo. Destaca-se que três processos que chegaram ao tribunal para homologação foram desmembrados em dissídios coletivos, o que gera um número total de nove homologações e dezoito dissídios julgados.

\section{Gráfico 2 - Resultado das ações trabalhistas de Juiz de Fora no Tribunal Regional do Trabalho da $3^{a}$ Região (1964-1974)}

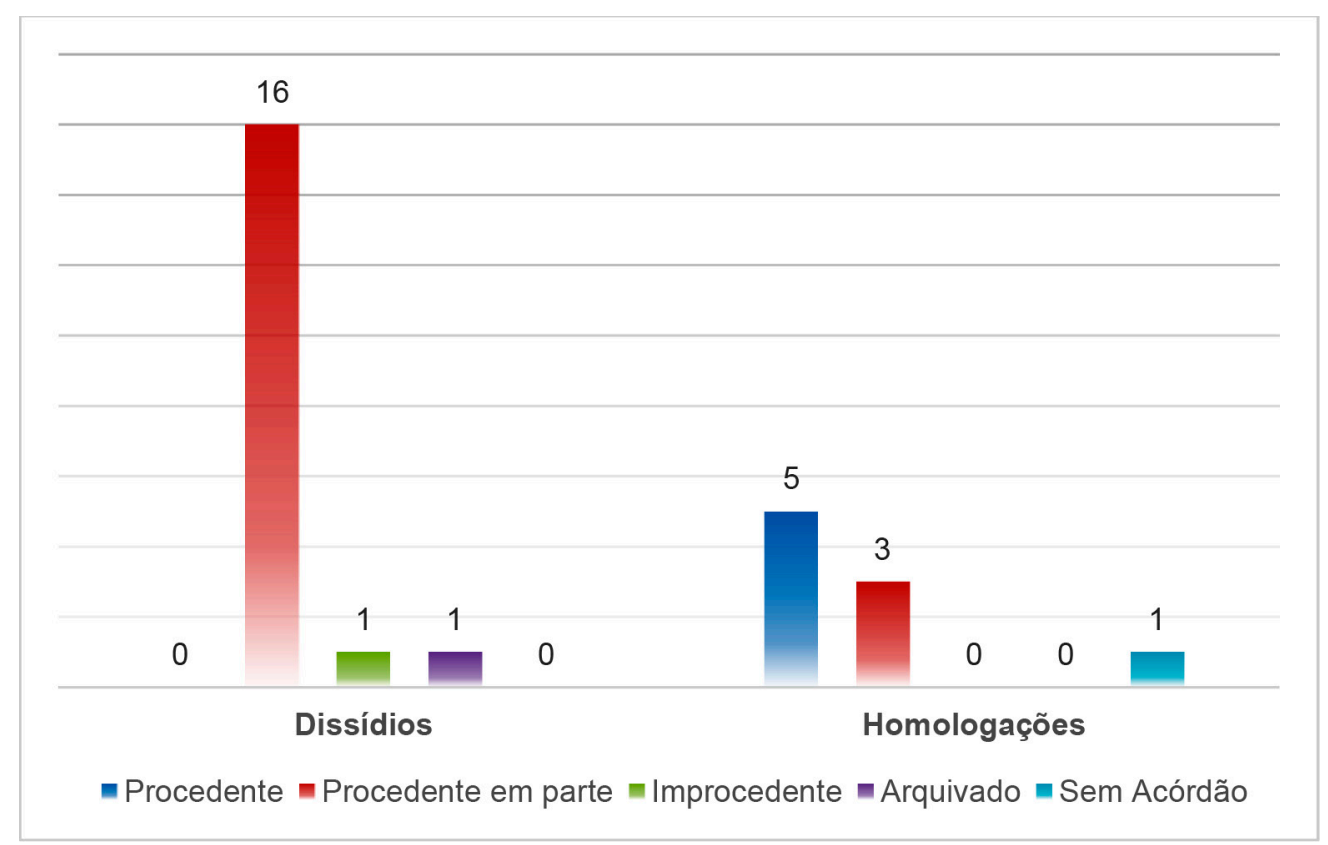

Fonte: Tribunal Regional do Trabalho da $3^{\text {a }}$ Região.

Para o caso dos dissídios coletivos, Fernando Teixeira da Silva percebeu que no TRT2 (São Paulo) os deferimentos parciais também prevaleceram por lá. Nesse sentido, o autor aponta que "as demandas dos trabalhadores na sua integralidade (deferimento total) tinham acolhida relativamente pequena entre os juízes, que tendiam a seguir o princípio salomônico de distribuir a matéria em disputa, prevalecendo assim, os deferimentos parciais [...]". ${ }^{67}$

66 TRT3, Processo n $5.628,1966$.

67 SILVA, Trabalhadores no tribunal, op. cit., 143. 
Com relação às homologações, os juízes eram mais receptivos, pelo fato daquele acordo a ser homologado ter sido livremente pactuado entre trabalhadores e empregadores. As palavras do juiz Curado Fleury durante o julgamento de uma ação impetrada pelo sindicato dos tecelões de Juiz de Fora revelam a percepção que tinham os juízes acerca das homologações: "[...] trata-se de um acordo entre as partes que pedem a sua homologação. Ora, a conciliação é instituto básico e fundamental do processo trabalhista e é obrigatória, visando à solução harmoniosa dos dissídios". 68

Como vimos, parte das reivindicações dos trabalhadores foi deferida pelo TRT3, mas o que de fato foi sentenciado pelo tribunal? Para responder tal questionamento será preciso analisar os aumentos salariais concedidos, relacionando-os com os valores oferecidos pelos patrões e com os índices de reajustamento informados pelos órgãos oficiais do governo ou pelo TST. O intuito é avaliar se os aumentos decretados foram benéficos ou não para os trabalhadores, bem como perceber se os índices do governo foram levados em consideração pelo tribunal. Do mesmo modo, serão identificados os demais direitos trabalhistas concedidos pelos juízes, tais como pisos salariais, férias, redução de jornada de trabalho e gratificações.

\section{Majoração salarial}

PARA REFLETIR acerca da majoração salarial, no sentido de perceber se os aumentos sentenciados reconstituíram o poder aquisitivo dos salários, foi necessário elaborar um parâmetro. Relacionou-se o valor ou porcentagem reclamada pelos trabalhadores com a proposta inicial ofertada pelos patrões, ou seja, aquilo que inicialmente estavam dispostos a pagar. Procedeu-se do mesmo modo com os índices fornecidos pelos órgãos oficiais do governo. Caso o aumento sentenciado fosse superior ao valor inicial oferecido pelos patrões ou aos índices oficiais, concluir-se-ia que os novos salários representaram os anseios dos trabalhadores. No caso das porcentagens informadas pelo governo, seria evidenciado, ainda, que as sentenças do tribunal não estiveram submetidas às leis e decretos baixados pelo Executivo. Contudo, se a majoração salarial sentenciada fosse inferior ou no mesmo patamar dos valores ofertados pelos patrões e/ou das taxas informadas pelo Executivo, seria demonstrado que o colegiado do TRT3 procurou propor uma fórmula conciliatória que não perdia de vista nem os interesses do patronato nem os do governo federal.

Salienta-se que tal metodologia só pode ser empregada para o caso dos dissídios, uma vez que os aumentos salariais via homologação representavam os interesses dos trabalhadores e dos patrões, devido à ocorrência de acordo livre e direto entre as partes. Quando do julgamento das homologações, o tribunal apenas referendava a porcentagem de aumento acordada.

68 TRT3, Processo $n^{\circ} 4.338,1964$. 
Cabe, então, conferir se os reajustes sentenciados nos dissídios coletivos foram ou não superiores aos aumentos propostos pelos empregadores e aos índices oficiais informados. Em nove dissídios, os patrões, representados ou não pela respectiva entidade patronal, não formularam nenhuma proposta de aumento. Eximiam-se com a alegação de que estavam impossibilitados de propor ou aceitar qualquer proposta conciliatória devido à incapacidade financeira das empresas de suportar nova majoração salarial de seus empregados. Nos demais dissídios, as empresas suscitadas chegaram a formular uma proposta conciliatória, ainda que, em processos contra mais de uma empresa, uma ou outra tivesse se negado a fazê-la. No entanto, ou essas propostas eram em bases bem inferiores ao que os trabalhadores pediam ou eram baseadas nos valores informados pelos órgãos oficiais, que, na maioria das vezes, eram também inferiores aos aumentos pleiteados.

Ao apurar os valores sentenciados, constatou-se que o TRT3 determinou reajustes salariais superiores aos que os patrões propuseram em aproximadamente $80 \%$ dos dissídios coletivos. Ainda que em mais da metade dos dissídios os respectivos aumentos salariais decretados pelo TRT3 tenham sido inferiores às porcentagens pleiteadas pelos trabalhadores, o fato dos novos salários serem maiores do que os valores oferecidos pelo patronato permite-nos afirmar que a correção salarial via dissídio coletivo era mais vantajosa aos trabalhadores, uma vez que, ao mesmo tempo que reparava parte dos danos causados pela política salarial da ditadura, beneficiava a categoria reivindicante.

Com relação aos índices informados pelos órgãos do governo, a partir da publicação do Decreto-Lei n 17, de 1966, o governo retirou a obrigação do Conselho Nacional de Economia (CNE) de informar os índices que deveriam ser levados em consideração quando do cálculo de reajustamento salarial. A partir daquele decreto, passou a se permitir que os tribunais trabalhistas corrigissem eventuais distorções salariais, desde que, para tal, o Tribunal Superior do Trabalho expedisse instruções, com força de prejulgado, a serem observadas pelos tribunais regionais do trabalho. Desse modo, os processos iniciados até 1965 ainda possuíam dados dos órgãos oficiais, tal como o SEPT ou o CNE. A partir de 1966, no entanto, passaram a ser observados apenas os cálculos realizados pelo TST, conforme instruções constantes dos prejulgados.

Ao todo, seis dissídios coletivos de Juiz de Fora tramitaram no TRT3 entre 1964 e 1965. Desses, dois possuíam dados do Serviço de Estatística da Previdência e Trabalho (SEPT), um do Departamento Nacional de Economia e Salário (DNES), e outros três não possuíam nenhum tipo de informação dos órgãos do governo. Daqueles três em que os órgãos do governo foram ouvidos, em dois os aumentos sentenciados pelo TRT3 foram superiores aos índices apurados, e em um o valor salarial reajustado foi exatamente igual à taxa informada. Havia certa desconfiança em relação aos dados do governo, que muitas vezes subestimava a inflação, conforme discutimos anteriormente.

Os demais dissídios, que, por sua vez, tramitaram entre 1966 e 1974, já continham cálculos elaborados conforme as normas dos prejulgados do TST. Desses, em sete o TRT3 determinou 
reajustes calculados sobre uma porcentagem levemente superior àquela encontrada pelos prejulgados do TST (na maioria dos casos isso acontecia devido a arredondamentos). Em outros três a taxa de reajustamento foi exatamente igual àquela encontrada nos cálculos do Tribunal Superior do Trabalho.

Desse modo, foram sentenciados, em mais da metade dos dissídios coletivos, aumentos salariais maiores que os valores informados pelos órgãos do governo. Ou seja, infere-se que, através das sentenças, os juízes do TRT3 procuraram não vincular os aumentos às normas estabelecidas pelas leis e decretos baixados pelos governos da ditadura. No entanto, quando o cálculo era informado pelo TST, os aumentos ou foram exatamente iguais às taxas informadas ou estiveram bastante próximos.

Portanto, a partir da leitura e análise dos dados referentes aos aumentos salariais sentenciados pelo Tribunal Regional do Trabalho da $3^{a}$ Região, conclui-se que tal tribunal buscou atuar com vistas em uma correção salarial mais justa para os trabalhadores, deferindo reajustes que realmente contribuíam para recuperação do poder aquisitivo dos assalariados. Em suma, os juízes do TRT3 estiveram, como vimos, denunciando as tentativas do Poder Executivo de cercear a ação do poder normativo conferido aos tribunais trabalhistas, bem como procuravam não seguir as taxas informadas pelos órgãos oficiais, porque traziam índices adulterados, muito inferiores à verdadeira elevação do custo de vida, tal como denunciou o juiz José Carlos Guimarães.

Ao reconhecerem que os salários estavam paulatinamente sendo atingidos pela elevação exorbitante do custo de vida, tendo em vista o descontrole inflacionário do período, os juízes acabavam por interferir na política salarial desenvolvida pelos governos da ditadura, o que gerava uma reação do Executivo no sentido de procurar, através de leis e decretos, restringir a atuação dos tribunais naquilo que dizia respeito aos aumentos salariais, ou seja, inviabilizar o poder normativo.

\section{Pequenas conquistas sentenciadas na forma de direitos}

EM RELAÇÃO ÀS DEMANDAS trabalhistas daqueles outros grupos de direitos destacados no Gráfico 1, devido aos seus teores de modificação de normas, tal como redução de jornada de trabalho, eram mais difíceis de serem concedidas pelos juízes. O Brasil já possuía, desde 1943, uma legislação dedicada ao tema dos direitos trabalhistas, a CLT, de modo que, em grande medida, os juízes entendiam que apenas através do Poder Legislativo seria possível modificar pontos de tal matéria. Essa era, inclusive, a argumentação do Ministério Público do Trabalho, que durante os julgamentos opinava para que esses direitos pleiteados, chamados de "vantagens", não fossem acolhidos pelo tribunal, pois as alterações trabalhistas pretendidas só poderiam ocorrer por força de lei. A exceção apenas se dava quando o objeto de reivindicação ainda não estava regulado por lei. 


\section{Gráfico 3 - Acolhida das demandas trabalhistas de Juiz de Fora no Tribunal Regional do Trabalho da $3^{\text {a }}$ Região (1964-1974)}

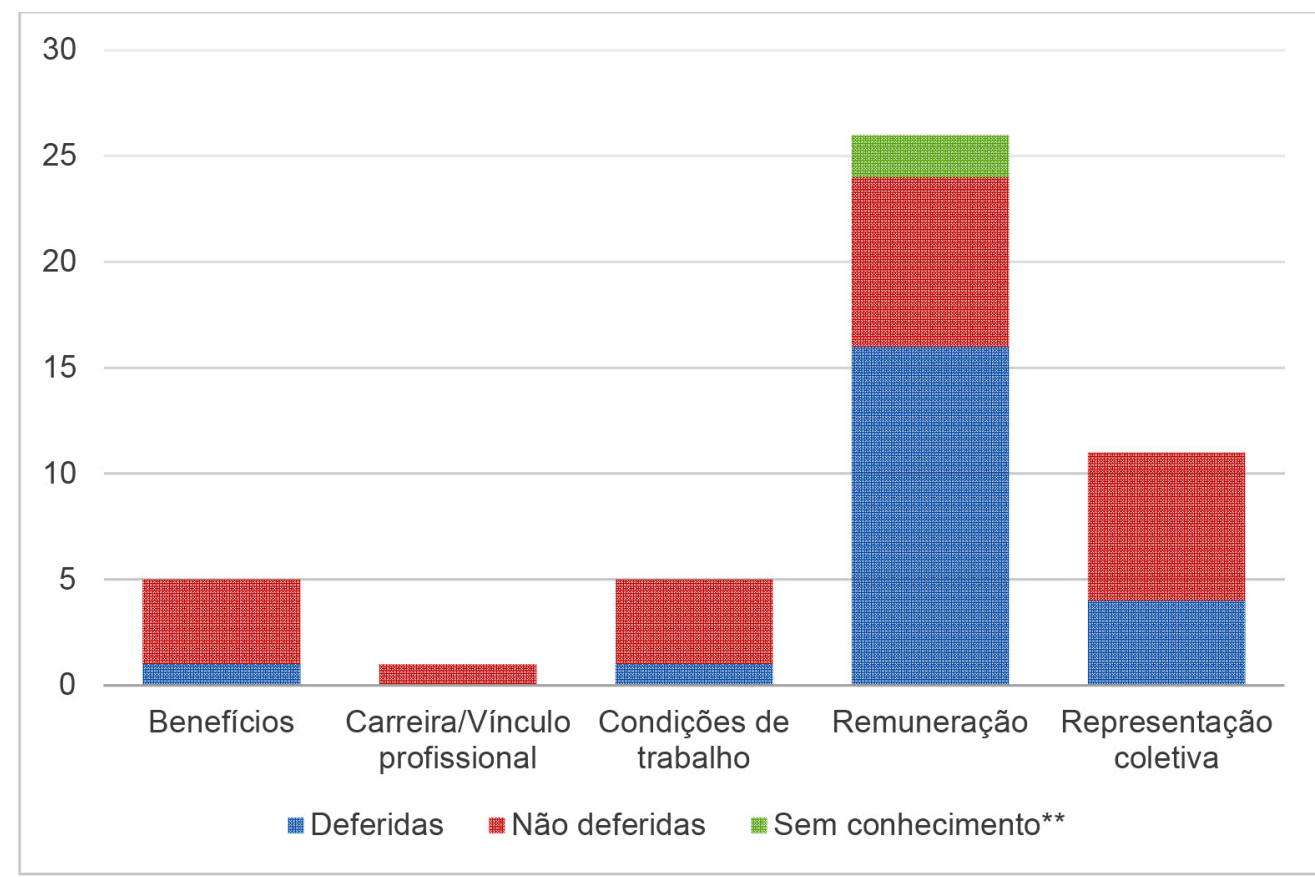

Fonte: Tribunal Regional do Trabalho da $3^{a}$ Região.

${ }^{* *}$ As duas demandas trabalhistas que não se tem conhecimento dos seus deferimentos fazem parte do Processo TRT3 n 1.246, de 1972, que não possui acórdão arquivado.

Pelos dados apresentados acima, infere-se que mais da metade das demandas pleiteadas pelos trabalhadores, excluídas as demandas por aumentos salariais, não foi acolhida pelo tribunal. As justificativas para o indeferimento se baseavam, também, na falta de informações suficientes para uma melhor análise dos pedidos e de suporte legal que corroborasse com o deferimento. Um exemplo está na ação movida pelo Sindicato dos Trabalhadores na Indústria da Energia Hidro-Elétrica de Juiz de Fora, quando o juiz relator Cândido Gomes de Freitas argumentou que o pedido relativo às férias em dobro, do grupo das remunerações, deveria ser indeferido, por falta de suporte legal. ${ }^{69}$

Outro processo que evidencia essas justificativas foi o impetrado pelo Sindicato dos Trabalhadores da Construção Civil de Juiz de Fora, em 1973, no qual o juiz relator Tardieu Pereira concluiu que a fixação de um piso salarial seria facultado ao tribunal, desde que justificada sua adoção, o que, para o juiz, não aconteceu. Nesse mesmo processo, os trabalhadores também reivindicavam um adicional aos salários daqueles profissionais que desenvolviam suas atividades com o uso de ferramentas próprias. Assim como para o caso do piso salarial, o relator do caso destacou que "a questão não veio exposta e debatida com dados e argumentos que permitam sua solução razoável". ${ }^{70}$ 
No entanto, dentro daquela outra metade de demandas que foram deferidas, há alguns casos significativos nos quais o TRT3 sentenciou direitos trabalhistas que modificaram as condições de trabalho de algumas categorias, ou concedeu benefícios que iam de encontro à política salarial da ditadura. É o caso, por exemplo, da ação impetrada pelos condutores de veículos rodoviários de Juiz de Fora. O tribunal concedeu, em acórdão publicado em janeiro de 1965 , a taxa de $5 \%$ por dia trabalhado fora da sede, que seria acrescida aos novos salários reajustados.

Já em abril de 1971, foi publicado o acórdão do dissídio que envolveu os Sindicatos dos Empregados em Estabelecimentos Bancários de Belo Horizonte, Juiz de Fora e Uberlândia e as sociedades de crédito, financiamento e investimentos sediadas naquelas cidades (Processo $n^{\circ}$ 2.380/70). Nessa ação, os trabalhadores vinculados a empresas que desenvolviam atividades de crédito, financiamento e investimento pleiteavam a concessão de direitos trabalhistas iguais aos que os bancários já possuíam, com a alegação de que desenvolviam atividades profissionais similares àquelas desenvolvidas dentro dos bancos. Desse modo, reivindicavam, entre outras coisas, a redução da jornada de trabalho para seis horas, a instituição de um piso salarial de admissão e um repasse ao sindicato, para o desenvolvimento de suas atividades jurídicas. As duas últimas pretensões foram acolhidas pelo tribunal.

Especificamente em relação ao repasse ao sindicato, o TRT3 vinha, pouco a pouco, cristalizando entendimento positivo ao desconto, dando "exegese mais consentânea com a realidade e as limitações do mandato legal atribuído às entidades sindicais, visto que só Ihes é dado conferir encargos à categorial em geral se previstos expressamente em lei". ${ }^{71}$ Em processos de anos anteriores a 1970, o tribunal vinha indeferindo o desconto salarial a favor do sindicato, ou determinando que o desconto fosse feito apenas sobre os salários dos trabalhadores sindicalizados. No caso em questão, além de ter deferido o repasse, ficou facultado, e não proibido, o desconto para aqueles que não fossem associados ao sindicato.

Por último, em outro dissídio envolvendo os trabalhadores das sociedades de crédito, financiamento e investimentos de Belo Horizonte, Juiz de Fora e Uberlândia (Processo $\left.n^{\circ} 3.135 / 72\right)$, desejava-se, novamente, que lhes fossem estendidos os benefícios já alcançados pelos bancários, dada a similitude das condições de emprego em atividades similares ou conexas, tal como era pleiteado na lide coletiva citada nos parágrafos anteriores. No dissídio agora em questão, além de um aumento salarial, os trabalhadores pleiteavam a liberação de um dirigente sindical, a redução da jornada de trabalho para seis horas, visto que havia sido indeferida no dissídio anterior, e aquele mesmo repasse salarial ao sindicato, quando do primeiro mês de aumento.

O juiz relator do caso Custódio Alberto de Freitas Lustosa indeferiu, em seu voto, a liberação de dirigente sindical e a redução da jornada de trabalho, tendo concedido apenas o aumento salarial e o desconto de parte do primeiro salário reajustado de cada trabalhador ao

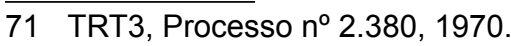


sindicato. Em relação à pretensão da nova jornada de trabalho, o juiz destacou que "a redução do horário de 8 para 6 horas, infringe a política salarial do governo, pois a redução do horário, sem redução do salário, o que é impossível, importa em remunerar, a maior, a hora de serviço. Os bancários desfrutam desta redução por força de lei art. 224 da CLT". ${ }^{72}$ O veto à liberação de dirigente sindical de suas funções foi mantido, mas o indeferimento à redução da jornada de trabalho foi derrubado pela maioria dos juízes que participaram do julgamento daquela ação, definindo, assim, o horário de trabalho em seis horas, tal como já usufruíam os bancários.

$\mathrm{Na}$ verdade, a redução da jornada de trabalho pleiteada nesse processo só foi possível porque a ação de 1970 (Processo $n^{\circ} 2.380 / 70$ ) foi alvo de recurso ordinário ao Tribunal Superior do Trabalho, pelo fato do TRT3 ter negado tal demanda. No julgamento do recurso ocorrido no TST, formou-se entendimento de que o regime de seis horas, tal como praticado pelos bancários, deveria ser estendido aos trabalhadores das financeiras e demais empresas de crédito, dada a similitude das funções desempenhadas. Por conta da jurisprudência formada no TST, e em respeito à hierarquia da Justiça do Trabalho, o TRT3 concedeu a redução da jornada de trabalho na ação de 1972 (Processo $n^{\circ} 3.135 / 72$ ), visto que envolvia as mesmas partes e o mesmo objeto de reclamação.

Contudo, ao avaliar o recurso dessa outra ação, o TST reverteu o entendimento que havia firmado no julgamento do recurso do processo $n^{\circ} 2.380 / 70$, determinando que somente por meio de dissídios individuais os empregados das empresas de crédito, financiamento e investimento poderiam reivindicar tal direito, pois a redução, nas palavras do ministro Thélio da Costa Monteiro, relator, "extravasava a competência normativa da Justiça do Trabalho". ${ }^{73}$ Apesar do revés, as empresas de crédito, financiamento e investimento, ainda que denominadas associações de poupança, cooperativas habitacionais, distribuidoras de títulos e valores e outros similares, foram incluídas na respectiva categoria econômica dos estabelecimentos bancários, equiparando o status dos respectivos trabalhadores.

Em 1973, os sindicatos instauraram novo dissídio coletivo, com intuito de não só renovar os direitos consagrados nos dissídios anteriores, mas de assegurar, por exemplo, a redução da jornada de trabalho, direito que ora era concedido ora era denegado. O TRT3, como havia feito no dissídio anterior (processo $n^{\circ} 3.135 / 72$ ), confirmou a jornada em seis horas diárias. Dessa vez, no entanto, maioria foi formada para manter a redução no TST, modificando novamente a jurisprudência em torno do tema.

Em suma, o que se viu nos dois processos em questão foi a conquista da equiparação profissional dos trabalhadores de instituições financeiras que exerciam função similar à dos bancários. De maneira geral, o TRT3 e o TST, por meio da competência normativa conferida aos tribunais trabalhistas, vinham aperfeiçoando a legislação trabalhista, sobretudo nos casos onde havia omissão.

72 TRT3, Processo n 3.135, 1972.

73 Ibidem. 


\section{Considerações finais}

Conclui-SE QUe, de fato, a Justiça do Trabalho se constituiu em um importante canal para ação e resistência dos trabalhadores durante a ditadura militar brasileira. Como vimos, o uso do judiciário trabalhista pelos trabalhadores e sindicatos representava, principalmente, uma possibilidade de atuação que visava duas coisas: a reconstituição dos salários de acordo com a elevação do custo de vida e os índices inflacionários e a melhoria nas condições de trabalho. Ou seja, através dos processos coletivos de trabalho e por meio da justiça, eles estiveram lutando por salários que fossem compatíveis com o custo de vida e contra a exploração da força de trabalho em um contexto que foi, do ponto de vista político, social e econômico, extremamente autoritário e desmobilizador.

A Justiça do Trabalho, por sua vez, através do instrumento do poder normativo, e no caso particular das ações de Juiz de Fora julgadas pelo Tribunal Regional do Trabalho da $3^{\text {a }}$ Região e pelo Tribunal Superior do Trabalho, no caso dos recursos, tornou possível que as classes trabalhadoras conquistassem as demandas reivindicadas. Mesmo as sentenças não tendo contemplado a integralidade das reivindicações, elas representaram expressivos ganhos, seja na majoração salarial que possibilitou a retomada do poder aquisitivo dos trabalhadores, seja no sentenciamento de novos direitos, tal como aconteceu com os trabalhadores das financeiras e demais empresas de crédito, que obtiveram a redução da jornada de trabalho e a equiparação profissional à categoria dos bancários.

Tendo em vista os contornos do Estado autoritário da ditadura militar, construído a partir de 1964 - sobretudo as políticas de restrição dos salários, a inflação descontrolada, a precarização das relações de trabalho e a repressão -, a Justiça do Trabalho, enquanto um espaço de negociação aberto aos trabalhadores, por meio de suas sentenças procurou proporcionar aos assalariados a reparação do seu poder aquisitivo, assim como avançar na matéria da legislação trabalhista.

Recebido em 14/07/2020

Aprovado em 03/02/2021 